\title{
LIGHT AND ELECTRON MICROSCOPE STUDY OF THE DIABETIC RAT MYOCARDIUM AFTER TRIMETAZIDINE (VASTAREL) TREATMENT
}

\author{
By \\ Gamal A. Mohamed \& Adel A. Al-Hawary
}

From

Anatomy Department, Faculty of Medicine, Mansoura University

\begin{abstract}
Diabetic patients with ischaemic heart disease have a greater liability of myocardial ischaemia, and an increased incidence of heart failure compared to the non-diabetic ones. The goal of this study was to clarify the effects of trimetazidine on the architecture of the myocardium of diabetic rats. Thirty adult male albino rats $(200-250 \mathrm{gm})$ were used in this investigation. They were divided into three equal groups; control, diabetic non-treated and diabetic TMZ- treated. At sacrifice, small pieces of the myocardium of left ventricle were processed for histological, histochemical and immunohistochemical study. Myocardium of diabetic rats showed an apparent increase of endomysium. The muscle fibers showed areas of degeneration. Ultrastructurally, the
\end{abstract}

cardiac myocytes of diabetic rats showed distortion of cardiac myofibrils with loss of cross banding in many areas. The nucleus had a corrugated nuclear membrane and the mitochondria were swollen and distorted. Histochemically, myocardium of diabetic rats exhibited a weak succinic dehydrogenase reaction and a strong positive immunoreaction for NF-kappa B and caspase-3 in myocardial sarcoplasm. On the other hand, TMZ- treated diabetic rats showed an improvement in the histological architecture and in both histochemical and immunohistochemical reactions. So, TMZ should always be advised for diabetic patients to alleviate the cardiac hazards.

\section{INTRODUCTION}

Diabetes mellitus (DM) is a chronic metabolic disorder charatcterized 
by widespread complications. Cardiovascular problems have become the major causes of morbidity and mortality in the diabetic population. (Kamal et al., 2005; Marzilli and Affinito, 2005). The long-standing DM can result in the development of cardiomyopathy regardless the coronary artery affection and may be accompanied by myocardial fihrosis (Kerrie et al., 2002; Akula et al., 2003). Several mechanisms are implicated in the pathogenesis of the functional and morphological changes of the myocardium of diabetic patients (Rosano et al., 2005).

Marzilli and Affinito (2005) reported that direct modulation of cardiac metabolic alterations associated with DM appears as a promising choice for the management of ischaemic heart disease. They found that trimetazidine (TMZ) could improve anginal patients without causing haemodynamic changes. El- Kady et al. (2005) and Saeedi et al. (2005) found that TMZ improves post-ischaemic function of pressure overload hypertrophied hearts. This drug intake with the routine treatment up to 18 months is well - tolerated and induces an imVol. 37, No. 1 \& 2 Jan., \& April, 2006 provement of the left ventricular func. tion (Di Napoli et al., 2005; O'Meara and McMurray, 2005). Kara et al. (2004) said that TMZ protects the heart against ischaemia-induced arrhythmias and reduces the myocardial infarct size in anaesthetized rats.

A review of the available literature revealed a lack of studies pertaining the histological effects of TMZ on the diabetic myocardium. Consequently, the present investigation was carried out with an intent to throw light on the histological, histochemical and immunohistochemical effects of TMZ on the myocardium of the diabetic albino rats.

\section{MATERIALS AND METHODS}

Thirty adult male albino rats (200$250 \mathrm{gm}$ ) were used in the present study. They were equally divided into three groups. Group I rats served as control. Group II and III animals were experimental and were given a single dose of streptozotocin (Sigma, St. Louis, MO, USA), $60 \mathrm{mg} / \mathrm{kg}$ i.p., to induce diabetes by specifically damaging pancreatic beta - cells. Successful induction of diabetes was confirmed by elevated blood glucose 
levels (more than $300 \mathrm{mg} / \mathrm{dl}$ ) (Aoki et al., 2001; Evelson et al., 2004). Eight weeks after injection of streptozotocin, group I and II animals were given normal saline $(1 \mathrm{ml} /$ day orally for six months). Diabetic animals of group III were given TMZ (Blister of modified release film coated $35 \mathrm{mg}$-tablets of trimetazidine dihydrochloride manufactured by Servier Egypt Industeries Limited, 6th October City, Egypt, in a dose of $70 \mathrm{mg}$ per day orally, dissolved in $1 \mathrm{ml}$ normal saline). Doses were given orally daily by a modified plastic syringe for six months (Qiu et al., 2005). The human dose of TMZ was corrected according to formula of Paget and Barnes, (1964). All animals were housed under the same conditions and allowed food and water ad-libitum.

\section{Histolgical study :}

Twenty-four hours after the last dose of TMZ, rats of all groups were anaesthetized by ether and sacrificed. Small pieces of the myocardium of left ventricle were immersed in $10 \%$ formalin, dehydrated, cleared and embedded in paraffin. Paraffin sections $(6 \mu \mathrm{m})$ were prepared and stained with haematoxylin \& eosin
(H\&E) to study the general histological architecture of the ventricular myocardium (Drury and Wallington, 1980).

For electron microscopy, fine fragments of the left ventricle were fixed in glutaraldehyde $(2 \%)$ in $0.1 \mathrm{M}$ phosphate buffer at $\mathrm{pH}$ 7.4. They were, then, transferred to $1 \%$ osmium tetroxide in the same buffer, dehydrated in ascending grades of alcohol and propylene oxide, embedded in epon (Hayat, 1989). Ultrathin sections $(40-50 \mathrm{~nm})$ were cut, using a glass knife, stained with $4 \%$ uranyl acetate, $2 \%$ lead citrate and examined by JEOL 100 S electron microscope.

\section{Histochemical study :}

Fresh frozen cryocut sections $(10 \mu \mathrm{m})$ were processed for nitro-blue tetrazolium (NBT) staining to estimate the succinic dehydrogenase enzyme (SDH) activity (Kiernan, 1999)

\section{Immunohistochemical study}

Paraffin sections of left ventricle (5 $\mu \mathrm{m})$ were stained by peroxidase antiperoxidase enzymatic immunohistochemical method(PAP) (Sternbargar et al., 1970), using anti nuclear factor- 
kappa B (NF-kappa B, Santa Cruz, USA) (Jones et al., 2003) and anti caspase-3 (Lab Vision, USA) antibodies, invasion system with 3- $3{ }^{\prime}$ diaminobenzidine tetrachloride hydrogen peroxidase solution (DAB) as chromogen. The sections were counter stained by Mayer's haematoxylin, dehydrated and mounted (Cai et al., 2002).

\section{RESULTS}

\section{Histological changes :}

The myocardium of the left ventricle of control rats (group I) showed branching and anastomosing striated muscle fibers separated by a narrow endomysium. They possessed acidophilic cytoplasm and central vesicular nuclei. Flat fibroblasts were noticed at the periphery of the fibers (Fig. 1). The myocardium of diabetic rats (group II) showed an apparent increase in the endomysium between cardiac muscle fibers with numerous fibroblasts. Muscle fibers exhibited areas of degeneration. Some nuclei appeared small and dark (Fig. 2). TMZtreated diabetic rats (group III) showed a slight increase of the endomysium. Cardiac muscle fibers were more or less similar to the control
(Fig. 3).

\section{Ultrastructural changes :}

The cardiac myocytes of group I rats exhibited evident cross striations formed by myofibrils. Sarcomeres were bounded by two successive $Z$ lines and showed a dark $A$ band and two halves of light I band. A band showed a lighter $\mathrm{H}$ zone in its center, which was bisected by dark $M$ line. The sarcoplasm lodged numerous mitochondria in rows between myofibrils and the nuclei had smooth outlines (Fig. 4). The cardiac myocyte of group II rats showed loss of the normal architecture with focal areas of degeneration. The mitochondria were swollen and distorted. The nuclei possessed corrugated nuclear membranes (Fig.5). An improvement in the histological picture of the cardiac myocyte of group III animals was observed in the form of reappearance of cross banding of sarcomeres. Normal dark bands were bisected by $\mathrm{H}$ zone and the light bands appeared very narrow. The nucleus was oval with smooth nuclear membrane. Some myofibrils were still degenerated. The mitochondria were arranged in rows 
between myofibrils (Fig.6).

Histochemical changes :

The myocardium of control rats (group I) showed an intense succinic dehydrogenase (SDH) reaction, which appeared as small purple granules scattered in the sarcoplasm of the muscle fibers (Fig. 7). In diabetic rats (group II), the reaction was mostly moderate (Fig. 8). TMZ treated diabetic rats (group III) exhibited an intense reaction in most fibers and a moderate one in some areas (Fig. 9).

Immunohistochemical changes :

1) Nuclear factor kappa B (NF kappa B) : Group I rats showed a weak expression of NF kappa B in the sarcoplasm of cardiac myocytes (Fig. 10). In group II rats, there was a strong positive immune reaction to NF kappa B, which appeared as brownish dots in the cytoplasm (Fig.11). In TMZ-treated diabetic rats (group III), the level of NF-Kappa B reaction in most of cardiac myocytes returned nearly to the control level (Fig.12).

2) Caspase- 3 : Group I rats showed a negative immune reaction to caspase- 3 in their myocardial sarcoplasm (Fig. 13). A strong positive immune reaction to caspase- 3 , was encountered in the cardiac myocytes of group II rats in the form of brownish punctate in the cytoplasm (Fig. 14). Group III animals exhibited a very weak reaction to caspase- 3 in most of their cardiac myocytes and strong reaction in the degenerated ones (Fig.15). 


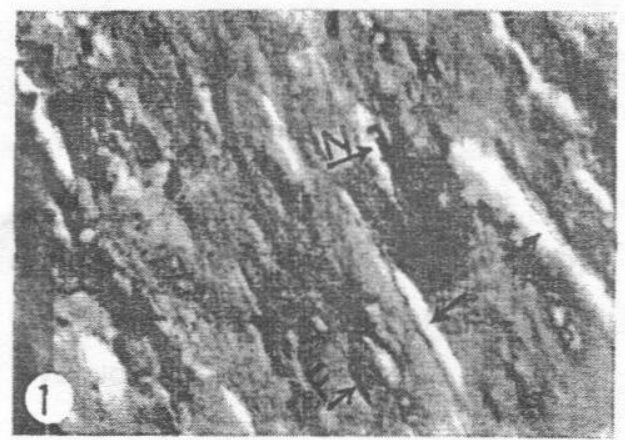

Fig. (1) : A photomicrograph of a control rat (group I) myocardium showing longitudinal striated muscle fibers with central vesicular nuclei (N). Notice the peripheral flat fibroblasts $(F)$ and the narrow endomysium (arrows). (H\&E.X400)

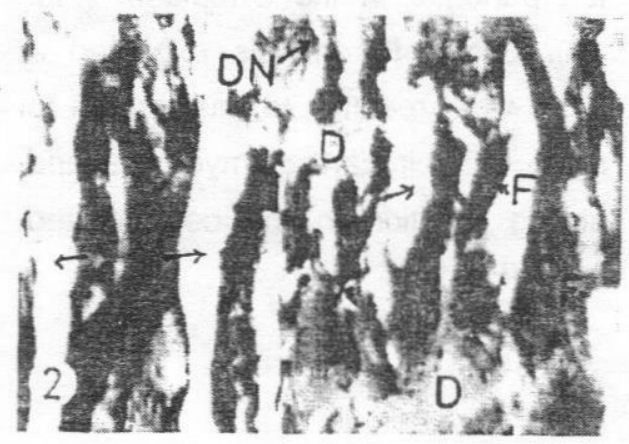

Fig. (2) : A photomicrograph of the myocardium of diabetic rat (group II) showing muscle fibers with areas of degeneration (D). The nuclei are small and dark (DN). Notice the numerous fibroblasts $(F)$ and the apparently increased endomysium (arrows). (H\&E.X 400).

Vol. 37, No. 1 \& 2 Jan., \& April, 2006

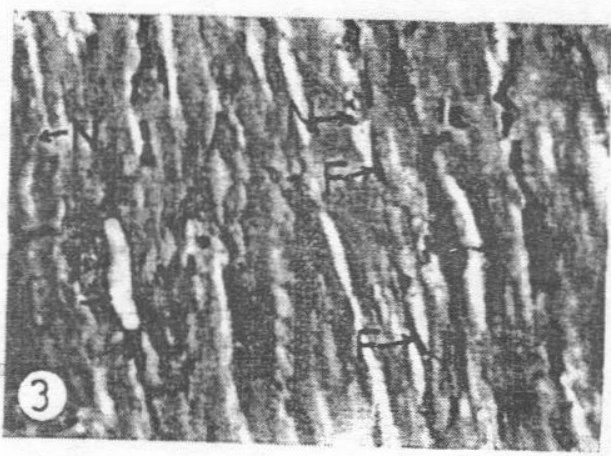

Fig.(3) : A photomicrograph of the myocardium of TMZ- treated diabetic rat (group III) showing a slight increase of endomysium (arrow).Muscle fibers are more or less similar to the control. Notice the vesicular oval nuclei

(N) and scattered fibroblasts (F). (H \& E. X 400).

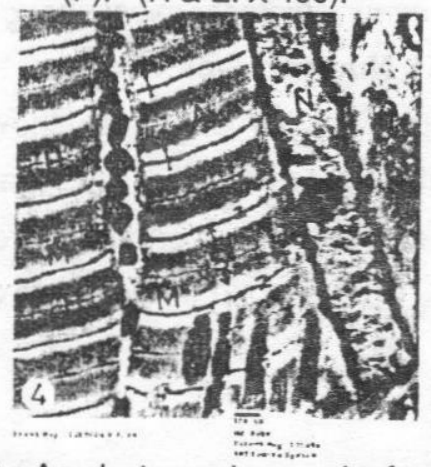

Fig.(4) : An electron micrograph of a control rat cardiac myocyte showing cross banding pattern of the myofibrils. Sarcomeres (S) lie between 2 successive Zlines $(Z)$ and showed dark bands (A) and light bands (I). A band showed a lighter $\mathrm{H}$ zone in its center, which was bisected by a dark $M$ line (M). Mitochondria $(m)$ lie between myofibrils in rows. Notice the oval nucleus $(\mathrm{N})$. (Uranyl acetate / lead citrate $X$ 10000). 


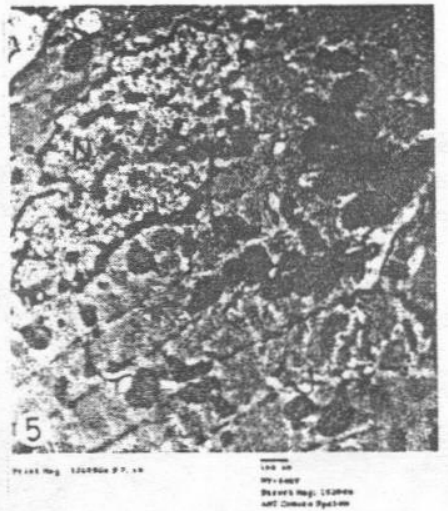

Fig.(5) : An electron micrograph of a cardiac myocyte of group II rat showing distortion of cardiac myofibrils with loss of cross banding in many areas. The nucleus $(\mathrm{N})$ has corrugated nuclear membrane and the mitochondria (M) are swollen and distorted. (Uranyl acetate / lead citrate X 10000).

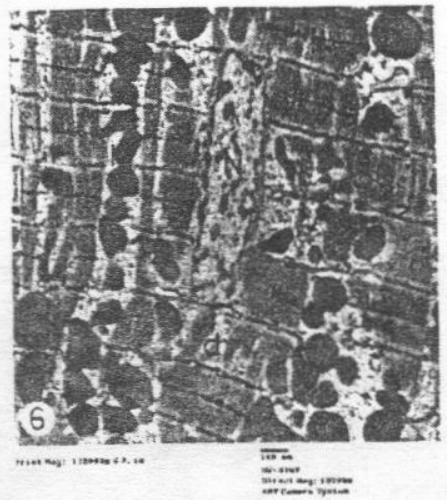

Fig.(6) : An electron micrograph of the cardiac myocyte of group III rat showing regular cross banding of sarcomeres (S).The dark bands are bisected by $\mathrm{H}$ zone and the light bands appear very narrow. The nucleus $(\mathrm{N})$ is oval with smooth nuclear membrane. Some myofibrils are still degenerated (d). Notice the mitochondria (M) arranged in rows between myofibrils. Uranyl acetate / lead citrate $\mathrm{x} 10000)$.

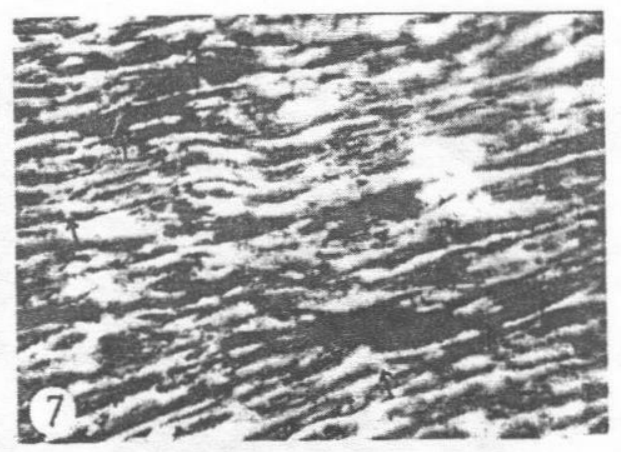

Fig.(7) : A photomicrograph of a control rat myocardium showing intense SDH enzyme activity of muscle fibers with no staining of intercalated disc (arrows). (NBT X 200).

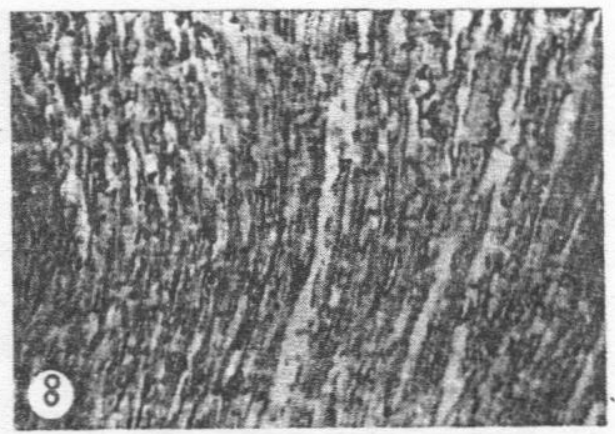

Fig.(8) : A photomicrograph of a diabetic rat myocardium showing mostly a moderate SDH enzyme activity. (NBT X 200).

MANSOURA MEDICAL JOURNAL 


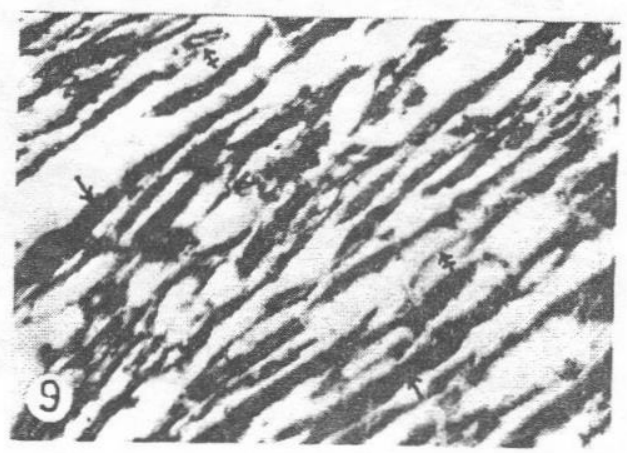

Fig.(9) : A photomicrograph of myocardium of diabetic rat treated with $\mathrm{TMZ}$ showing an intense SDH reaction in most fibers (arrows) and moderate reaction in few areas. (crossed arrows). (NBT X 200).

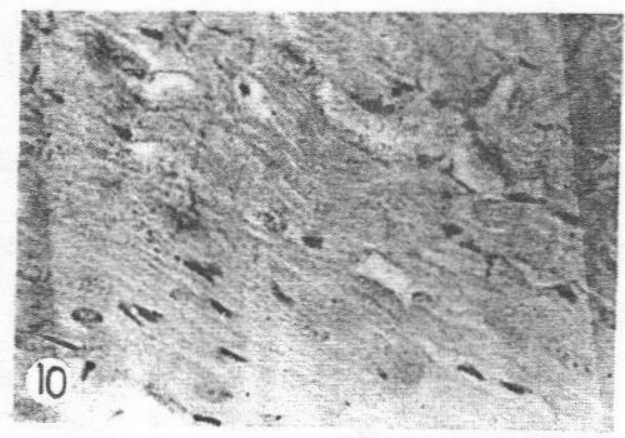

Fig.(10) : A photomicrograph of a control rat myocardium showing weak expression of NF- kappa B in the cytoplasm of myocardium. (PAP x 400).

Vol. 37, No. 1 \& 2 Jan., \& April, 2006

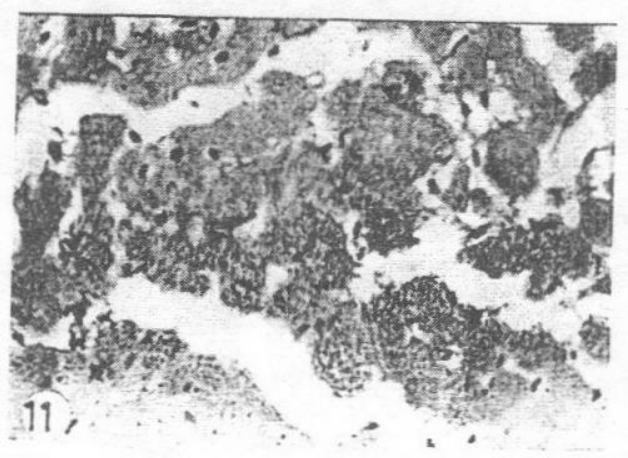

Fig.(11) : A photomicrograph of myocardium diabetic rat showing strong NF-Kappa B reaction in cadriomyocytes. (PAP X 400).

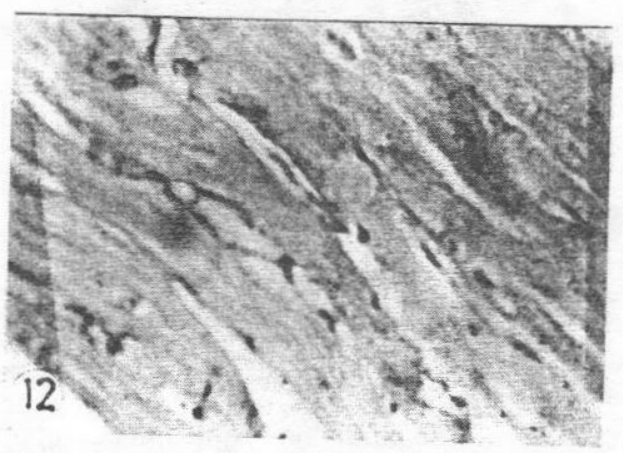

Fig.(12) : A photomicrograph of myocardium of TMZ- treated diabetic rat showing control level of NF. Kappa $\mathrm{B}$ reaction in most of cadiomyocytes. (PAP X 400). 


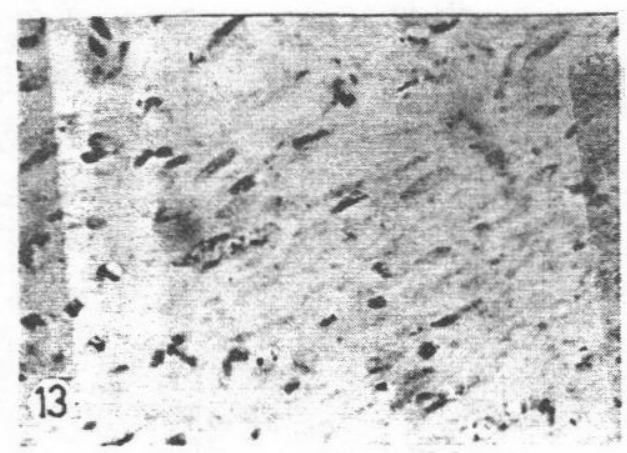

Fig.(13) : A photomicrograph of the control rat myocardium showing negative reaction to caspase3 in the cytoplasm of cardiac myocytes.

(PAP X 400).

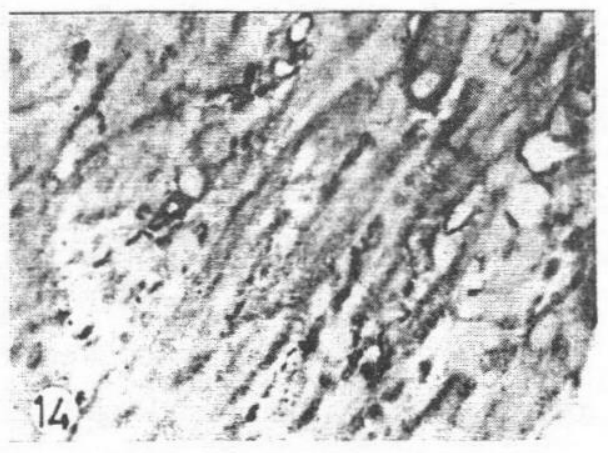

Fig.(14) : A photomicrograph of the myocardium of diabetic rat showing strong reaction to caspase- 3 (PAP X 400).

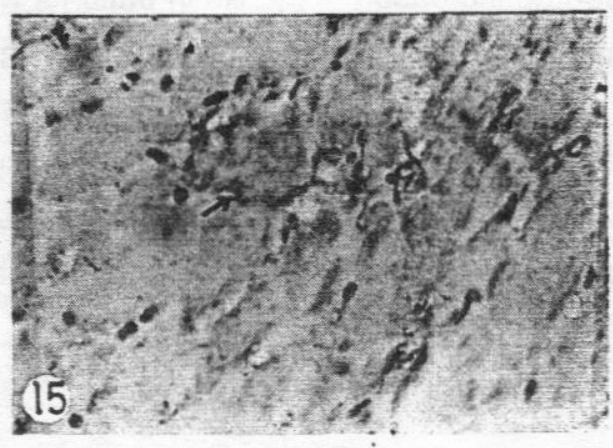

Fig.(15) : A photomicrograph of the myocardium of TMZ- treated diabetic rat showing a very weak reaction to caspase- 3 in the majority of cardiac myocytes with area of strong reaction (arrow) in the degenerated fibers. (PAP X 400). 


\section{DISCUSSION}

The prevalence of ischaemic heart disease complicating diabetic syndrome is growing rapidly. Management of such a problem remains a challenge; treatments are less effective in diabetic patients than in non diabetic ones. The greater occurrence of ischaemic heart disease is partially due to coronary artery disease and, more importantly, due to the diabetes-induced abnormalities in the myocardium, termed diabetic cardiomyopathy (Marzilli and Affinito, 2005; Stanley, 2005). This cardiomyopathy may be accompanied by myocardial fibrosis (Akula et al., 2003). Rosano et al., (2005) found that the increased uptake and oxidation of free fatty acid by myocardial tissue is responsible for the increased susceptibility of the diabetic heart to myocardial ischaemia compared to the nondiabetic ones.

In the present study, the myocardium of diabetic rats showed an in- creased endomysium between cardiac muscle fibers with numerous fibroblasts. Muscle fibers showed areas of degeneration. Some nuclei appeared small and dark. These alterations could be due to the diabetic hyperglycaemia and coincides with Thompson et al. (1991), Kerrie et al. (2002) and Adeghate (2004). The wide endomysium, noticed in the present work, could be due to the decreased size of degenerated cardiac muscle fibers. In the current investigation, the myocardium of the TMZ- treated diabetic rats, more or less, regained the control features. This could be due to the effect of TMZ which might combat the hazards of DM on the myocardium. El-Kady et al. (2005) postulated that TMZ improves the ischaemic attacks in patients with ischaemic cardiomyopathy clinically without haemodynamic alterations. Moreover, Parang et al. (2005) claimed that TMZ works by enhancing the efficiency of the myocardium, rather than decreasing its work. 


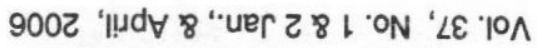

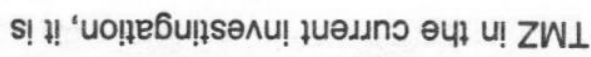

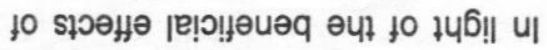

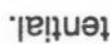

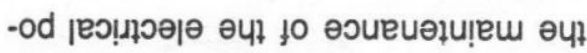

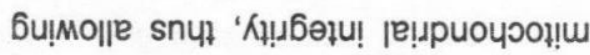

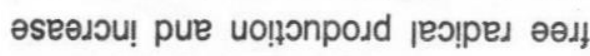

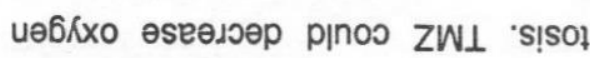

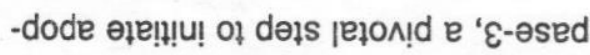

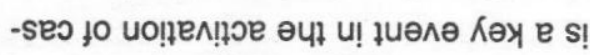

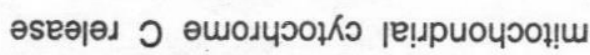

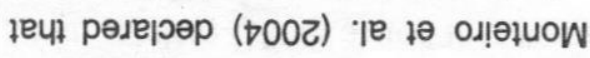

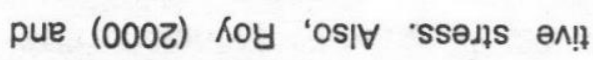
-ep!xo se yons 'suo!̣ppuos э!̣oldode -odd to kienjer e jepun sisojdode u! ә0д ұueนodu! ue Ke|d e!̣puouว

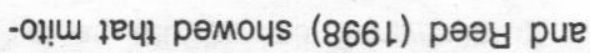

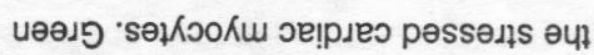

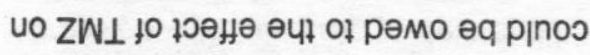

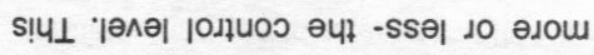

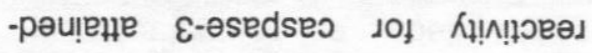
-ounwm! 'Kpnłs łuәдno әцł u! 'słed

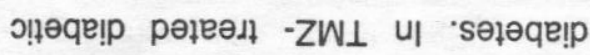

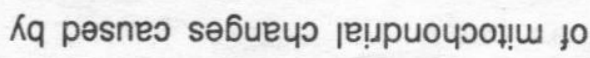

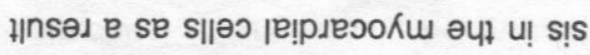

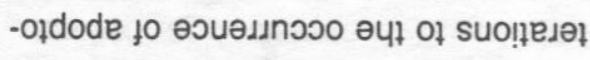

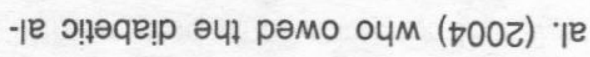

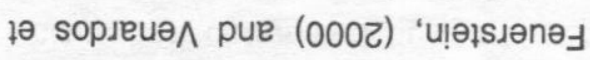

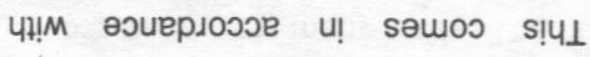

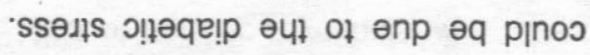

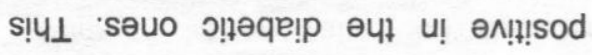
бuods sem म! ә!!

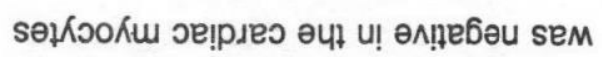

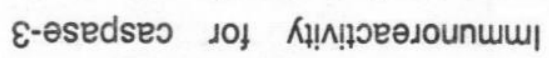

's॥อว

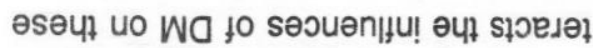

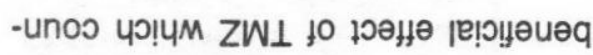

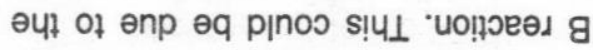

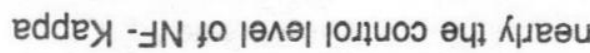

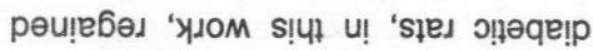

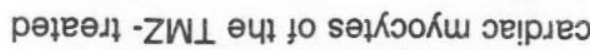
әцा ұо łsow '

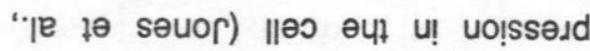
-xә pue uo!̣epedదəp p!̣des sı! əsneo

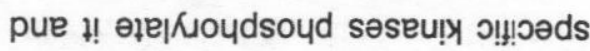

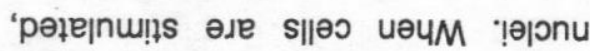

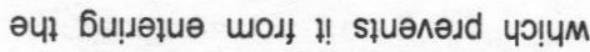

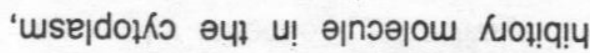
-U! of punoq S! म! 's॥əo peiłe|nu!̣sun u|

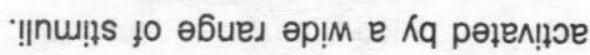
әq 아 punof uəəq seu 8 eddex-JN

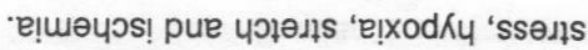

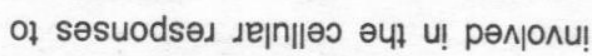
osje s! \& eddex- $-\mathrm{N}$ leuł peppe (†00Z)

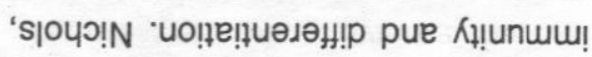

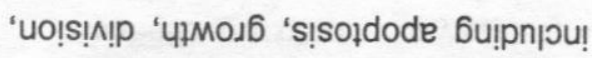

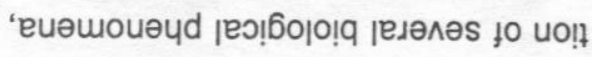

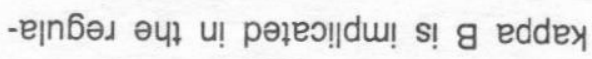

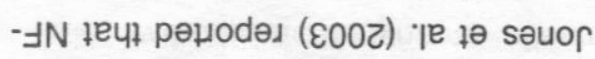

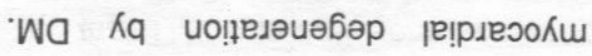
әцा 아 әnp әq p|nos s!̣। pәseәдо -u! sem \& eddeY्र-」N to uo!ssend 


\section{ᄀ}

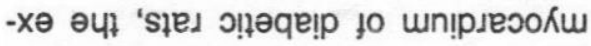

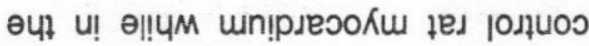
әцा u! uo!̣sseddxә уеәм е рәмоцs

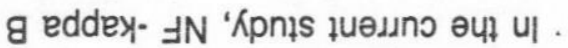

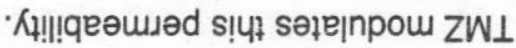

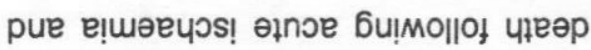

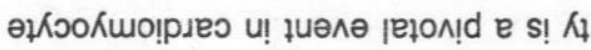

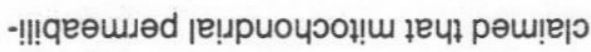

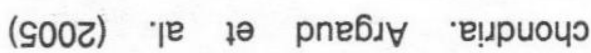

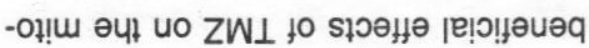
әцң 아 әnp әq p|nо s! әц! 6u!̣quesed sıəq!! łsom u! uo!? -oead has әsuәju! ue pәmous 'Kpnıs

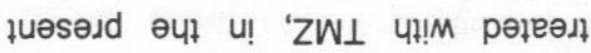

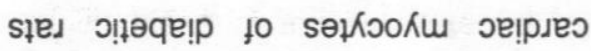

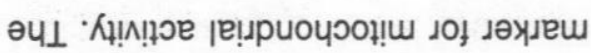
e se pesn s! pue uo!̣onpodd K6ృəuə

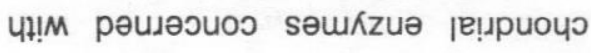
-оң!س әцा to әuо s! HOS leul pәppe

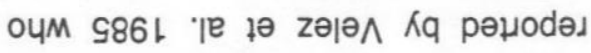

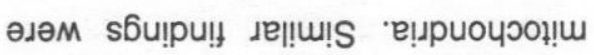
рәдә|је of рәмо әq pןnos чэ!чм 'ио!! -әеәд (HOS) әseuәболрКцәр э!u!эons

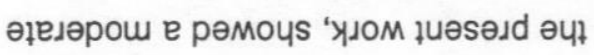

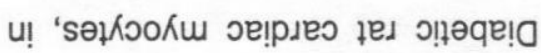

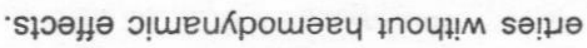

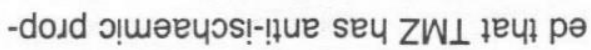
-ppe очм (c00z) ' "ן

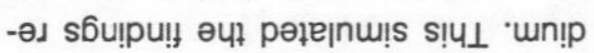

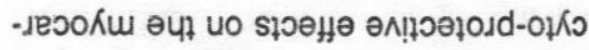

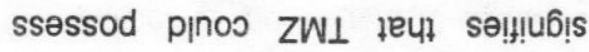

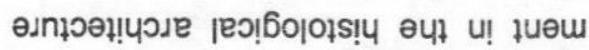

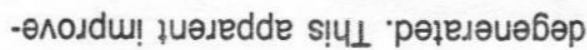

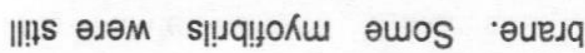

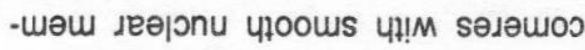

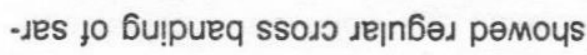

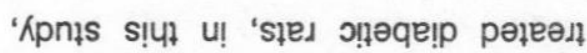

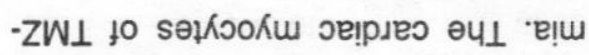
-әеכאןbjadK4 kq pasneo sseдs әк!!

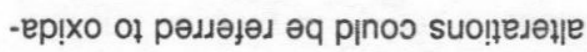

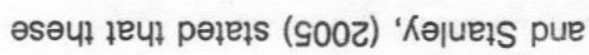

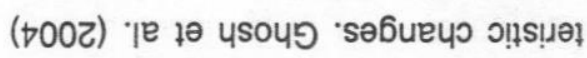

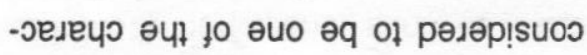
әдәм sәnss!! э!ฺәqе̣p u! suo!̣edәң|е

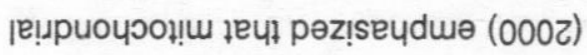

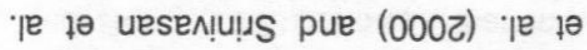

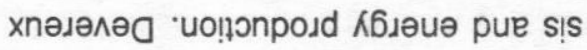

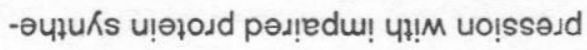

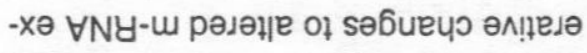

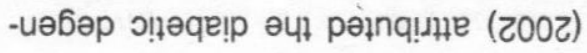

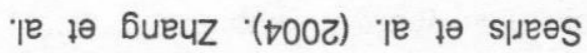

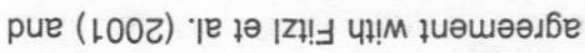

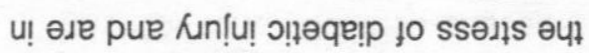
of рәмо әq p|nos s6u!pu!! ןednı๐ns

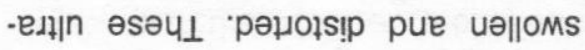
әдәм ецриочәоाш әцा рuе әиедq

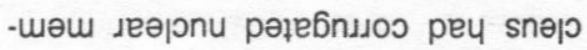
-nu әчц 'seәле Kuew u! Gu!pueq ssojo

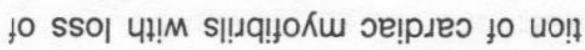

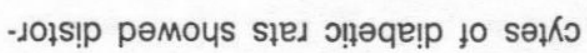

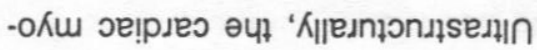


advisable to widen the scale of its use for patients at high risk of diabetes mellitus to alleviate the diabetic undesirable cardiac hazards.

\section{REFERENCES}

Adeghate, E. (2004) : "Molecular and cellular basis of the aetiolo. gy and management of diabetic cardiomyopathy: a short review". Mol Cell Biochem. 261 (1-2): 187 - 191.

Akula, A. ; Kota, M.K. ; Gopisetty, S.G. and Chitrapu, R.V. (2003) : "Biochemical, histological and echocardiographic changes during experimental cardiomyopathy in STZ-induced diabetic rats". ". Pharmacol Res 48 (5): 429-435.

Aoki, M.; Morishita, R.; Hayashi, S.; Jo, N.; Matsumoto, K.; Nakamura, T.; Kaneda, Y. and Ogihara, T. (2001) : Inhibition of neointimal formation after balloon injury by cilostazol, accompanied by improvement of endothelial dysfunction and induction of hepatocyte growth factor in rat diabetes model. Diabetologia 44: 1034-1042.

Argaud, L.; Gomez, L. and GateauRoesch, O., (2005) : Trimetazidine inhibits mitochondrial permeability transition pore opening and prevents lethal ischemiareperfusion injury. J Mol Cell Cardiol. 39(6):893-9.

Cai, L.; Wei, L.; Guangwu, W. and Luping, G. (2002) : Hyperglycemia- induced apoptosis in mouse myocardium. Diabetes 51: 1938- 1948.

Devereux, R. B.; Roman, M.J.; Paranicas, M. and O'Grady, M. J. (2000) : "Impact of diabetes on cardiac structure and function: the strong heart study". Circulation 10: $2271-2276$.

Di Napoli, P.; Taccardi, A.A. and Barsotti, A. (2005) : Long term cardioprotective action of trimetazidine and potential effect on the inflammaMANSOURA MEDICAL JOURNAL 
tory process in patients with ischaemic dilated cardiomyopathy. Heart. 91(2):1615.

Drury, R. A. B. and Wallington, E. A. (1980) : "Carleton's Histological Techniques". 5th ed. Oxford. New York. London: $140-141$.

El-Kady, T.; El-Sabban, K.; Gabaly, M.; Sabry, A. and AbdelHady S, (2005) : Effects of trimetazidine on myocardial perfusion and the contractile response of chronically dysfunctional myocardium in ischemic cardiomyopathy: a 24-month study. Am.J,Cardiovasc.Drugs. 5 (4):271-278.

Eveison, P.; Llesuy, S.; Filingel, E. and Rodriguez (2004) : Decreased oxidative stress in prehepatic portal hypertensive rat livers following the induction of diabetes. Clinical and experim pharamcol, and physiol. 31: 169-173.

Vol. 37, No. 1 \& 2 Jan., \& April, 2006
Feuerstein, G.Z. and Young, P.R. (2000) : "Apoptosis in cardiac diseases: stress- and mitogen-activated signaling pathways". Cardiovasc. Res $45: 560-569$.

Fitzl, G.; Welt, K.; Wassilew, G.; Clemens, N.; Penka, K. and Mukke, N. (2001) : "The influence of hypoxia on the myocardium of experimentally diabetic rats with and without protection by Ginkgo biloba extract. III: Ultrastructural investigations on mitochondria". Exp Toxicol Pathol. 52 (6) : 557 . 568.

Ghosh, S.; Qi, D.; An, D.; Pulinilkunnil, T. and Abrahani, A. (2004) : "Brief episode of STZ-induced hyperglycemia produces cardiac abnormalities in rats fed a diet rich in $n-6$ PUFA". Am J Physiol Heart Circ Physiol. 287 (6): H 2518 - 2527.

Green, D. R. and Reed, J. C. (1998) : "Mitochondria and apopto- 
sis". Science 281: 1309 1312.

Hayat, M. (1989) : Principles and Techniques of Electron Microcopy, Bioligical applications. 3rd ed., CRC press, New York, Florida, 24-74.

Jones, W.K.; Brown, M.; Ren, X. H. S. and McGuinness, M. (2003) : "NF-kappaB as an integrator of diverse signaling pathways: the heart of myocardial signaling? . Cardiovasc Toxicol. 3 (3) : 229 $-254$.

Jun, X. U.; Jun, X. I. E. and Minsheng, B. A. O. (2003) : "NF-kappaB/I-kappaB pathway during ischemia reperfusion injury of rat liver". Chin Med J 116: 1146 1149.

Kamal, A.; Biessels G.J.; Ramakers G.M.J. and Gispen W. H. (2005) : The effect of short duration streptozotocin- induced diabetes mellitus on the late phase and thers- hold of long- term potentiation induction in the rat. Brain res. 1053: 126- 130.

Kara, A.F.; Demiryurek, S.; Celik $A$,Tarakcioglu $M$ and Demiryurek A.T (2004) : Effects of trimetazidine on myocardial preconditioning in anesthetized rats. Eur. J. Pharmacol. 25; 503 (13):135-140.

Kerrie, J.; Keiji, I.; Kiyoshi, S. and Tamotsu, Y. (2002) : "Expression of Connective Tissue Growth Factor Is Increased in Injured Myocardium Associated With Protein Kinase C $\beta 2$ Activation and Diabetes". Diabetes 51: 2709 -2718.

Kiernan, J. A. (1999) : "Histological and Histochemical Methods". 3rd ed. Butter Warths, London, Boston:, $319-320$.

Marzilli, M.; and Affinito, S. (2005) : Meeting the challenge of chronic ischaemic heart disMANSOURA MEDICAL JOURNAL 
ease with trimetazidine. Coron. Artery Dis. 16 Suppl 1:S23-27.

Monteiro, P.; Duarte, A.I.; Goncalves, L.M.; Moreno, A.; and Providencia, L.A. (2004) : Protective effect of trimetazidine on myocardial mitochondrial function in an ex-vivo model of global myocardial ischemia. Eur $\mathrm{J}$ Pharmacol. 25; 503(1-3) : 123-128.

Nichols, T. C. (2004) : "NF-kappaB and reperfusion injury". Drug News Perspect. 17 (2) : 99 - 104.

O'Meara, E. and McMurray, J.J. (2005) : Myocardial metabolic manipulation: a new therapeutic approach in heart failure? Heart. 91 (2):131-2.

Paget, G.E. and Barnes, J.M. (1964) : Evaluation of drug activities. Pharmacometrics. Vol. I. Academic Press, New York. In, Fundamentals of

Vol. 37, No. 1 \& 2 Jan., \& April, 2006
Experimental Pharmacology 2nd edition, Ghosh M.N. (ed) (1988) scientific Book Agency Calcutta, P. 155.

Parang, P.; Singh, B. and Arora, R. (2005) : Metabolic modulators for chronic cardiac ischemia. J. Cardiovasc. Pharmacol. Ther. 10 (4):217-223.

Qiu, Z.X.; Ma, H.J. and Wang, D.F. (2005) : Therapeutic value of trimetazidine in patients with coronary heart disease and left ventricular dysfunction] Zhonghua Xin Xue Guan Bing Za Zhi. 33 (9):793-5. (English abstract)

Rosano, G.M.; Vitale,C.; Volterrani, M. and Fini, M. (2005) : Metabolic therapy for the diabetic patients with ischaemic heart disease. 16 Suppl 1:S17-21.

Roy, S. (2000) : "Caspase at the heart of the apoptotic cell death pathway". Chem Res Toxicol 13 : 961 - 962 . Eur 
J Pharmacol: 503(1-3):1238.

Saeedi, R.; Grist, M. and Wamblot, R.B. (2005) : Trimetazidine normalizes postischemic function of hypertrophied rat hearts. J. Pharmacol. Exp Ther. 314 (1):446-54.

Searls, Y. M.; Smirnova, I. V.; Fegley, B. R. and StehnoBittel, L. (2004) : "Exercise attenuates diabetesinduced ultrastructural changes in rat cardiac tissue". Med Sci Sports Exerc. $36(11)$ : 1863 - 1870.

Srinivasan, S.; Stevens, M. and Wiley, J. W. (2000) : "Diabetic peripheral neuropathy: evidence for apoptosis and associated mitochondrial dysfunction". Diabetes 49 : 1932 -1938.

Stanley, W.C. (2005) : Rationale for a metabolic approach in diabetic coronary patients. Coron.Artery Dis. 16 Suppl 1S :5-11.
Sternbargar, L. A.; Hardy, P. H.; Cuculus, J. I. and Meyer, H. G. (1970) : "The unlabelled antibody enzyme method of immunohistochemistry preparation and properties of soluble antigen antibody complex \{Horse radish peroxidaseantihorse radish peroxidase". J. Histoch. Cytochem. 18: 315 - 333.

Thompson, E. W. ; Baker, J. C. ; Kamoss, S. A. and Anderson, W. H. (1991) : "The severity of diabetes is a major determinant of myocardial damage in the rat". Proc Soc Exp Biol Med. 196 (2) : $230-233$.

Velez, M.; Machado, M. and Satrustegui, J. (1985) : "Age dependent modifications of rat heart succinic dehydrogenase". Mech. Aging. Dev. $32(2-3)$ : $131-140$.

Venardos, K.; Harrison, G.; Headrick, J. and Perkins, A. (2004) : "Auranofin increasMANSOURA MEDICAL JOURNAL 

LIGHT AND ELECTRON MICROSCOPE STUDY etc..

es apoptosis and ischaemia-reperfusion injury in the rat isolated heart". Clin Exp Pharmacol Physiol. 31 (56): $289-294$.

Zhang, F.; Li G.; Ding W.; Liu Y. and Xie C. (2002) : "Screening and analysis of early cardiopathologyrelated gene in type 2 diabetes mellitus". Zhonghua Nei Ke Za Zhi. 41(8):530-3. (English abstract). 


\section{دراسة بالمدهر الضوخى والإلكترونى لعضلة قلب الفأر المصاب بالسكر بعد علاجها بعقار ترايميتازيلين (فستاريل)}

د. جمال أبو الفتوح محمد د. عادل عبد المهدى الهوارى من قسم التشريح - كلية الطب - جامعة المنصورة

أجرى هذا البحث لكشف أثر تعاطى عقار ترايميتازيدين (فستاريل) على قلوب الفئران المصابة بمرض السكر. وقد اسـتخدم فى البحث ثلاثون من ذكور الفئران البيضاء البالغة تراوح وزنها بين

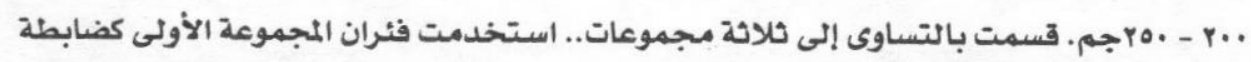
وفتران المجمموعة الثانية تم إصـابتها بمرض السكر وفنـران المجموعة الثالثة تم إصابتها بمرض السكر وأعطيت عقـار ترايميتازيدين (فستاريل) بعد ثمانية أسابيع من الإصـابة بالسكر واستمـر العلاج ستة أشهر متتالية عن طريق الفم مرة يومياً. وقد أظهرت الدراسـة الهستولوجية والهستوكيميائية والمناعية الهستوكيميائية التغيرات المصاحبة للاصسابة بمرض السكر على عضلة القلب من فقد لترتيب الالياف العضلية ميع اتساع فى الغشاء البينى بينها ووجود تحلل فى بعض هذه الأنياف. وأصبحت الأنوية صغيرة داكنة وجدارها

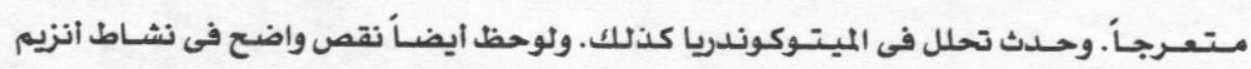
السكسينـيك ديهـيدروجينيـزوزيادة فى التـفـاعل المناعى للكابا والكسبـاس-r ـ وقد حـث تحسن ملحوظ وغير تام على عضلة القلب بعد اعطاء عقار ترايميتازيدين (فستاريل) ادى الى استعادة الالياف العضلية لمعظم تركيبها الطبيعى كما قلل التفاعل المناعى والكيميائى الدال على تحلل النخلايا. ويعد استعراض النتائج السـابقة يمكن الإستنتاج أن عقار ترايميتازيدين (فستاريل) مفيد لعضلة القلب التى تتاثر بمضاعفا ت مرض البسكر. 
